\title{
Variation in trophic resources in female South American sea lions at a small geographic scale
}

\author{
M. Florencia Grandi ${ }^{1}$ (1) | Damián G. Vales $^{1}$ (i) | Enrique A. Crespo ${ }^{1,2}$ (i) | \\ Rocío Loizaga ${ }^{1}$ (1)
}

${ }^{1}$ Laboratorio de Mamíferos Marinos, Centro para el Estudio de Sistemas Marinos, CONICET, Puerto Madryn, Chubut, Argentina ${ }^{2}$ Universidad Nacional de la Patagonia San Juan Bosco, Puerto Madryn, Chubut,

Argentina

\section{Correspondence}

Dra. María Florencia Grandi, Laboratorio de Mamíferos Marinos, Centro para el Estudio de Sistemas Marinos, CONICET, Bvd. Brown 2915, (U9120ACD) Puerto Madryn, Chubut, Argentina.

Email: grandi@cenpat-conicet.gob.ar

Funding information

Agencia Nacional de Promoción Científica y Tecnológica, Grant/Award Number: PICT0216/2013; Fundación BBVA, Grant/ Award Number: BIOCON08 194/09; PADI Foundation, Grant/Award Number: Grant \#31802; Zoo d'Amnéville, Grant/Award Number: 2008

\begin{abstract}
Difference among colonies in the population structure of otariids can be driven by philopatry and/or by specializations in the foraging ecology of females. In northern Patagonia, the South American sea lion (SASL) shows some degree of spatial genetic structure among colonies from north and south zones. This study aims to explore the isotopic niche of SASL females in the last period of the pregnancy from different colonies of northern Patagonia and to consider whether the fine scale genetic spatial structuring is potentially related to variation in trophic resources. Stable isotope analysis was performed on 101 skin samples of newborn pups in 10 colonies, as a proxy for the feeding ecology of their mothers. Differences among colonies in the metrics studied revealed the plasticity of the species and support individual trophic specialization of SASL females at a small geographic scale. Also, significant differences were found in all isotopic metrics between the north and south zones. Several hypotheses were proposed to explain the differences in SASL females' isotope values (e.g., use of different foraging areas or prey, isotopic baseline variation). Nonetheless, further research is needed to better understand the relation between fine scale genetic structuring and the foraging ecology of SASL females.
\end{abstract}

\section{KEYWORDS}

Argentina, $\delta^{13} \mathrm{C}, \delta^{15} \mathrm{~N}$, northern Patagonia, Otaria flavescens, stable isotope analysis, trophic ecology 


\section{1 | INTRODUCTION}

The diversity of habitat in marine ecosystems influences trophic behavior of marine predators, depending on the level of competition to which they are exposed. Overall, populations that inhabit low productivity systems face strong intraspecific competition, which leads to the development of different foraging strategies to maximize nutritional efficiency (Páez-Rosas, Villegas-Amtmann, \& Costa, 2017). Diversification of feeding habits at inter- and intrapopulation levels is thought to be an ecological and evolutionary adaptation, influencing the genetic structure and dynamics of certain populations (Kernaléguen, Arnould, Guinet, \& Cherel, 2015; Matich, Heithaus, \& Layman, 2011; Newsome et al., 2015).

For some otariids, such as the New Zealand sea lion, Phocarctos hookeri, California sea lion, Zalophus californianus, Antarctic fur seal, Arctocephalus gazella, and Steller sea lion, Eumetopias jubatus, the population structure was found to be driven by female philopatry, i.e., natal site fidelity (Collins, Chilvers, Osborne, Taylor, \& Robertson, 2017; González-Suárez, Flatz, Aurioles-Gamboa, Hedrick, \& Gerber, 2009; Hoffman \& Forcada, 2012; Hoffman, Matson, Amos, Loughlin, \& Bickham, 2006). However, for some sea lion species (e.g., the Galapagos sea lion, Zalophus wollebaeki, and Australian sea lion, Neophoca cinerea) the population structure seems to be defined by differences in the foraging ecology of females among colonies (Jeglinski, Wolf, Werner, Costa, \& Trillmich, 2015; Lowther, Harcourt, \& Goldsworthy, 2013; Lowther, Harcourt, Goldsworthy, \& Stow, 2012; Páez-Rosas et al., 2017).

South American sea lion, Otaria byronia ${ }^{1}$ (SASL), populations are recovering from historical sealing. Particularly in northern Patagonia (Argentina), SASL colonies are spatially clustered (Grandi, Dans, \& Crespo, 2008, 2015). This pattern of distribution of colonies could be the consequence of a complex recolonization process involving dispersal, philopatry, available terrestrial suitable habitat, closeness to high productivity areas, site fidelity to feeding grounds, and breeding success (Grandi et al., 2008, 2018).

Genetic studies revealed a strong female philopatry for SASLs in the Southwestern Atlantic Ocean (coast of Uruguay, Patagonia, and Falkland Islands/Malvinas), while gene flow is mediated by males (Feijoo, Lessa, Loizaga de Castro, \& Crespo, 2011; Hoffman et al., 2016; Oliveira et al., 2017; Túnez, Centrón, Cappozzo, \& Cassini, 2007; Túnez, Cappozzo, Nardelli, \& Cassini, 2010). At a regional geographical scale (i.e., Patagonian coast; Figure 1) distinct female population units were distinguished among groups of colonies in northern and central Patagonia, southern Patagonia, and the Falkland Islands (Malvinas) (Feijoo et al., 2011; Hoffman et al., 2016; Túnez et al., 2007, 2010). On a smaller scale (i.e., SASL colonies distributed over $\sim 250 \mathrm{~km}$ in northern Patagonia), the level of female philopatry and consequently genetic population structure is weak. However, some level of spatial genetic differentiation seems to exist between colonies from north and south zones (Figure 1; Grandi et al., 2018). At this spatial scale (i.e., north and south zones of northern Patagonia), habitats differ greatly in their physiography, oceanography, and prey availability (Jarma et al., 2019, and references therein). Furthermore, stomach content analysis has revealed a small scale variation in the diet of the SASLs in the Patagonian region, with individuals feeding mostly on demersal pelagic fish on the north zone (San Matías Gulf, 41-42 ${ }^{\circ}$; Figure 1) and mainly on benthic species on the south zone (Nuevo Gulf, 42-43 S; Figure 1) (Jarma et al., 2019).

The SASL has been considered a generalist and opportunistic predator (Cappozzo \& Perrin, 2009). The species has the plasticity to adapt and modify their feeding behavior, taking advantage of a wide variety of prey along its Atlantic distribution (Koen Alonso, Crespo, Pedraza, García, \& Coscarella, 2000; Jarma et al., 2019; Szteren, Naya, \& Arim, 2004; Thompson, Duck, McConnell, \& Garrett, 1998). Moreover, recent stable isotope analysis studies of female SASLs revealed two important trophic behavioral strategies. First, adult females have patterns of individual foraging specialization (Baylis et al., 2015, 2016a; Franco-Trecu, Aurioles-Gamboa, \& Inchausti, 2014). Second, they showed long-term fidelity (years) to discrete foraging habitats (Baylis et al., 2015, 2016a; Baylis, Orben, Costa, Arnould, \& Staniland, 2016b).

In recent years, the use of cost-effective stable carbon and nitrogen isotopes have become a powerful methodology to study the trophic ecology at the inter- and intrapopulation levels in marine mammals (Crawford, MacDonald, \& Bearshop, 2008; Newsome, Clementz, \& Koch, 2010). While $\delta^{15} \mathrm{~N}$ values provide data on trophic level (Post, 2002; Vander Zanden \& Rasmussen, 1999), $\delta^{13} \mathrm{C}$ values reveal information on feeding habitats (coastal/oceanic, pelagic/benthic) used by consumers (Hobson, Schell, Renouf, \& Noseworthy, 1996). The isotopic data have the advantage of 
integrating diet information of consumers over different periods, such as days, months, or years, depending on the tissue of the consumer. It has been suggested that pups can be used as proxy for maternal foraging since their isotopic compositions derive from tissues of their mothers during in utero development (Baylis et al., 2016a; Drago et al., 2010; Franco-Trecu, Aurioles-Gamboa, Arim, \& Lima, 2012). Hence, $\delta^{13} \mathrm{C}$ and $\delta^{15} \mathrm{~N}$ values in pinniped pups' skin provide a proxy for adult females' trophic ecology during the last period of the pregnancy, with differences among pups reflecting individual differences in the diet and habitat use of their mothers (Aurioles, Koch, \& Le Boeuf, 2006; Baylis et al., 2016a; Drago et al., 2010; Ducatez, Dalloyau, Richard, Guinet, \& Cherel, 2008; Franco-Trecu et al., 2012).

Individual specialization is an ecological and evolutionary process that may have important influences on population dynamics and could be the force in population structuring process (Araújo, Bolnick, \& Layman 2011; Bolnick et al., 2003, Pettorelli, Coulson, Durant, \& Gaillard, 2011). Hence, understanding SASL individual feeding strategies, especially in breeding females, is crucial for determining population dynamics in a recovery and recolonization context. Therefore, the aims of this study are (1) to explore the isotopic niche of the female SASLs belonging to different colonies of northern Patagonia during the last period of the pregnancy and (2) to consider whether the fine scale genetic population structure in adult female SASLs is related to their foraging ecology.

\section{2 | MATERIALS AND METHODS}

\subsection{Study area and sampling}

The study was conducted in 10 colonies of SASL during the 2013 breeding season, in northern Patagonia, Argentina (roughly between $41^{\circ}$ and $43^{\circ} \mathrm{S}$; Figure 1 , Table 1 ). With the purpose of illustrating the small scale of the study,
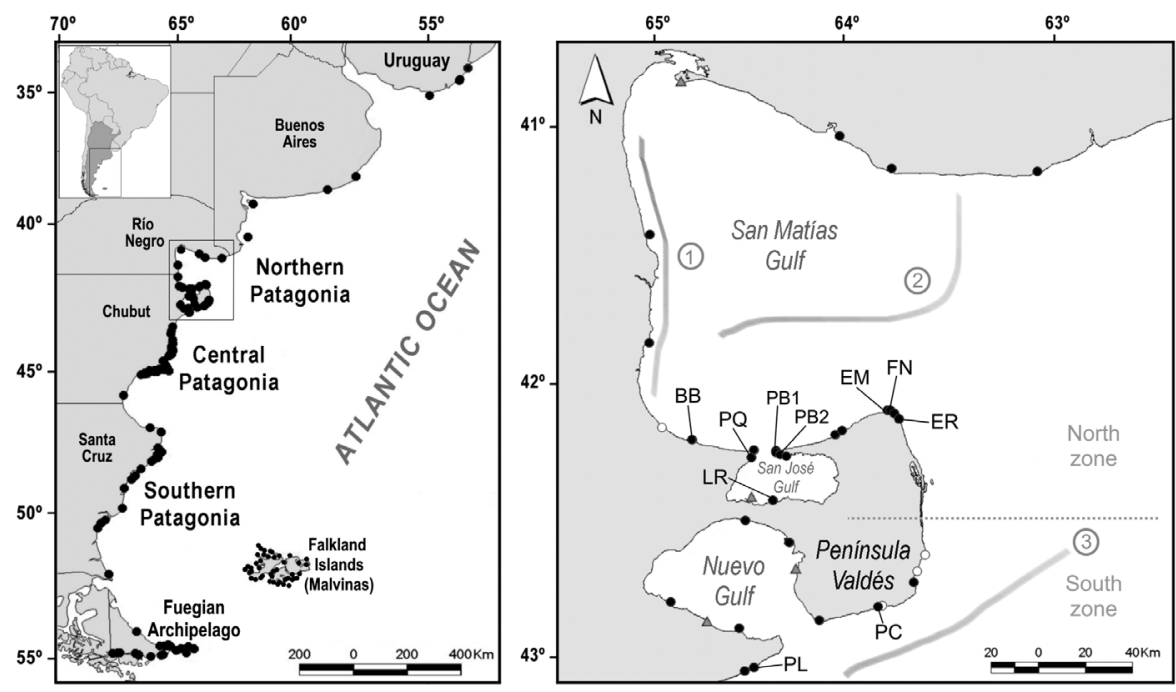

FIGURE 1 Left: current distribution of South American sea lion, Otaria byronia (SASL) colonies along the coast of the southwestern Atlantic Ocean. The box inside the map denotes the study area in northern Patagonia. Right: details of the distribution, type of colonies, and sampling sites in the study area (black circles: breeding colonies, white circles: haul-out colonies, gray triangles: occasional colonies). Thick gray lines locate oceanographic features: 1-Coastal upwelling events (Pisoni et al., 2014), 2-Thermohaline front (Piola \& Scasso 1988) and 3- Península Valdés tidal front (Tonini et al. 2013). Names of colonies (ID) are BB: Barrancas Blancas, PQ: Pta. Quiroga G. San José, LR: Larralde, PB1 Pta. Buenos Aires G. San José 1, PB2: Pta. Buenos Aires G. San José 2, EM: Ensenada Medina, FN: Faro Pta. Norte, ER: La Ernestina, PC: La Pastosa cría and PL: Pta. León Norte. Horizontal dotted line delimits groups of colonies following the spatial genetic pattern (i.e., north and south zones). 
TABLE 1 ID and colony names of South American sea lion at northern Patagonia. Sample size, $\delta^{13} \mathrm{C}, \delta^{15} \mathrm{~N}$ mean $( \pm S D$ ) isotopic values in skin of SASL newborn pups (\%o), centroid location (CL), mean Euclidean distance to centroid (CD), and Standard Ellipse Area $\left(S E A_{C}\right.$ and $S_{B} A_{B}$ ) for each colony. Different lowercase letters indicate RPP and LSD post hoc statistically significant differences among colonies $(p<.05)$.

\begin{tabular}{|c|c|c|c|c|c|c|c|c|}
\hline ID & Colony & $\mathrm{n}$ & $\delta^{13} C( \pm S D)$ & $\delta^{15} \mathrm{~N}( \pm S D)$ & $\mathrm{CL}$ & $C D$ & $\mathrm{SEA}_{C}$ & $\mathrm{SEA}_{B}( \pm S D)$ \\
\hline BB & Barrancas Blancas & 10 & $-14.16 \pm 0.47$ & $22.21 \pm 0.57^{a b c}$ & $-14.16 ; 22.21^{a}$ & $0.670^{a b}$ & 0.926 & $0.88 \pm 0.34^{\mathrm{ab}}$ \\
\hline$P Q$ & $\begin{array}{l}\text { Pta. Quiroga } \\
\text { G. San José }\end{array}$ & 10 & $-13.65 \pm 0.83$ & $21.75 \pm 0.63^{a b}$ & $-13.65 ; 21.75^{a}$ & $0.883^{a b}$ & 1.860 & $1.69 \pm 0.80^{c}$ \\
\hline LR & Larralde & 10 & $-13.62 \pm 0.41$ & $21.85 \pm 0.72^{\mathrm{ab}}$ & $-13.62 ; 21.85^{a}$ & $0.575^{\mathrm{ab}}$ & 0.691 & $0.74 \pm 0.27^{a}$ \\
\hline PB1 & $\begin{array}{l}\text { Pta. Buenos Aires } \\
\text { G. San José } 1\end{array}$ & 11 & $-13.55 \pm 0.37$ & $22.68 \pm 0.57^{c}$ & $-13.55 ; 22.68^{b}$ & $0.513^{a}$ & 0.677 & $0.67 \pm 0.23^{a}$ \\
\hline PB2 & $\begin{array}{l}\text { Pta. Buenos Aires } \\
\text { G. San José } 2\end{array}$ & 10 & $-13.92 \pm 0.46$ & $22.32 \pm 0.57^{\mathrm{ac}}$ & $-13.92 ; 22.32^{\mathrm{ab}}$ & $0.646^{a b}$ & 0.620 & $0.68 \pm 0.25^{a}$ \\
\hline EM & Ensenada Medina & 10 & $-13.92 \pm 0.58$ & $21.64 \pm 0.79^{b}$ & $-13.92 ; 21.64^{a}$ & $0.810^{\mathrm{ab}}$ & 1.574 & $1.42 \pm 0.65^{c}$ \\
\hline $\mathrm{FN}$ & Faro Pta. Norte & 10 & $-13.99 \pm 0.61$ & $21.7 \pm 0.74^{\mathrm{ab}}$ & $-13.99 ; 21.70^{a}$ & $0.846^{a b}$ & 1.610 & $1.44 \pm 0.68^{c}$ \\
\hline ER & La Ernestina & 10 & $-13.81 \pm 0.60$ & $21.89 \pm 0.86^{a b}$ & $-13.81 ; 21.89^{a}$ & $0.859^{a b}$ & 1.752 & $1.61 \pm 0.76^{c}$ \\
\hline PC & La Pastosa cría & 10 & $-14.23 \pm 0.57$ & $20.63 \pm 0.96^{d}$ & $-14.23 ; 20.63^{c}$ & $0.926^{b}$ & 1.289 & $1.28 \pm 0.59^{b c}$ \\
\hline $\mathrm{PL}$ & Pta. León Norte & 10 & $-14.18 \pm 0.72$ & $20.92 \pm 0.82^{d}$ & $-14.18 ; 20.92^{c}$ & $0.916^{b}$ & 1.506 & $1.47 \pm 0.68^{c}$ \\
\hline
\end{tabular}

TAB LE 2 Overlap index (top diagonal) and geographical distances (bottom diagonal in kilometers) between colonies of South American sea lion at northern Patagonia. Bold numbers indicate statistically significant overlap between colonies.

\begin{tabular}{|c|c|c|c|c|c|c|c|c|c|c|}
\hline Colony & BB & $P Q$ & LR & PB1 & PB2 & EM & FN & ER & PC & PL \\
\hline BB & & 0.48 & 0.05 & 0.13 & 0.45 & 0.50 & 0.58 & 0.60 & 0.00 & 0.00 \\
\hline$P Q$ & 32.49 & & 0.63 & 0.15 & 0.35 & 1.27 & 1.23 & 1.36 & 0.25 & 0.47 \\
\hline LR & 53.13 & 20.64 & & 0.13 & 0.02 & 0.54 & 0.55 & 0.68 & 0.18 & 0.27 \\
\hline PB1 & 37.70 & 10.74 & 20.31 & & 0.29 & 0.14 & 0.15 & 0.37 & 0.00 & 0.00 \\
\hline PB2 & 40.02 & 12.77 & 20.07 & 2.32 & & 0.38 & 0.40 & 0.57 & 0.00 & 0.00 \\
\hline EM & 82.69 & 62.04 & 73.08 & 54.23 & 56.55 & & 1.44 & 1.33 & 0.44 & 0.72 \\
\hline FN & 84.69 & 63.28 & 74.32 & 55.47 & 57.79 & 1.24 & & 1.32 & 0.39 & 0.64 \\
\hline ER & 89.90 & 69.11 & 80.15 & 61.30 & 63.62 & 7.07 & 5.83 & & 0.32 & 0.54 \\
\hline PC & 186.41 & 165.62 & 176.66 & 157.81 & 160.13 & 103.58 & 102.34 & 96.51 & & 0.98 \\
\hline $\mathrm{PL}$ & 250.17 & 229.68 & 240.42 & 224.05 & 223.89 & 167.34 & 168.58 & 160.27 & 61.07 & \\
\hline
\end{tabular}

geographical distance among colonies was calculated as the minimum distance (kilometers) required for a sea lion swimming from the midpoint of one colony to the midpoint of all others (Grandi et al., 2008, 2018). As a result, geographical distances between colonies range from 1.24 to $250.17 \mathrm{~km}$ with a mean and standard deviation of 92.58 $\pm 72.09 \mathrm{~km}$, whereas distances between colonies from north and south zones ranged from 96.51 to $250.17 \mathrm{~km}$, with a mean and standard deviation of $175.82 \pm 48.48 \mathrm{~km}$ (Table 2). Between 10 and 11 newborn pups were captured randomly at each colony (Table 1) using a noose pole (Gentry \& Holt, 1982). Newborn pups were less than 7 days old, as determined by the scarring state of the navel (Ameghino, 2012). Skin samples were taken from the trailing edge of the hind flippers and were stored in $20 \%$ dimethyl sulfoxide saturated with salt and kept at $-20^{\circ} \mathrm{C}$ (Amos \& Hoelzel, 1991). These samples were first used for genetic analysis (Grandi et al., 2018), and then used for isotope analysis. 


\subsection{Stable isotope analysis}

For pinnipeds, stable isotope ratios in skin samples are expected to integrate dietary inputs over 1-3 months prior to collection (Hobson et al., 1996; Kurle \& Worthy, 2001). Specifically, skin samples collected from SASL pups seem to be good proxies to investigate female trophic ecology because differences are negligible between isotopic values of female to pup discrimination factor in this tissue (Drago, Franco-Treco, Cardona, \& Inchausti, 2015). Considering that the median birth date for SASL occurs in mid-January (Campagna, 1985), skin pup isotopic values are used here as a proxy of the trophic ecology of female SASLs during the last 3 months of pregnancy (i.e., from mid-November to mid-January is the last period of the pregnancy; Franco-Trecu et al., 2012; Sepúlveda et al., 2017).

Skin samples preserved with DMSO were lipid extracted with three consecutive $\sim 24 \mathrm{hr}$ soaks in a 2:1 chloroform:methanol solvent solution, then rinsed five times in deionized water and lyophilized at $-40^{\circ} \mathrm{C}$ (Newsome, Koch, Etnier, \& Aurioles-Gamboa, 2006; Newsome, Chivers, \& Kowalewski, 2018). Both long-term DMSO preservation and lipid-extraction are expected to have no influence on carbon and nitrogen isotope ratios in skin (Newsome et al., 2018). Samples were analyzed at the Center for Stable Isotopes, University of New Mexico. Means and standard deviations of reference materials were $0.11 \%$ and $0.20 \%$ for $\delta^{13} \mathrm{C}$ and $\delta^{15} \mathrm{~N}$ values, respectively.

\section{3 | Data analyses}

The normality and homoscedasticity of raw isotopic data were tested using Shapiro-Wilks and Levene's tests, respectively. The carbon:nitrogen (C:N) ratio was calculated to assess lipid removal efficiency (Newsome et al., 2010). Stable isotope metrics (Layman, Arrington, Montaña, \& Post, 2007) were calculated for each colony and used to compare the trophic ecology of females among sites. These metrics are: (1) $\delta^{13} \mathrm{C}$ range (CR) provides an idea for niche diversification at the base of a food web; (2) $\delta^{15} \mathrm{~N}$ range (NR) suggests the amount of trophic levels and thus the degree of trophic diversity; (3) mean Euclidean distance to centroid (CD)-where centroid is the mean value of a group of $\delta^{13} \mathrm{C}-\delta^{15} \mathrm{~N}$ points in the delta space-provides additional information on isotopic niche width, but also gives a measure of spacing among individuals, the average degree of trophic diversity and, indirectly, its redundancy (Micheli \& Halpern, 2005). Variations in the $\delta^{13} \mathrm{C}$ and $\delta^{15} \mathrm{~N}$ ranges were compared among colonies using an analysis of variance (ANOVA). Multiple comparisons were performed using a Fisher LSD post hoc test. Also, differences in isotope niche location (i.e., distance between centroid locations, $\mathrm{CL}$ ) and niche width (CD) were compared following the "hypothesis testing framework" proposed by Turner, Collyer, and Krabbenhoft (2010). This analytical approach allows the study of distances between $\mathrm{CL}$ and absolute values of $\mathrm{CD}$ differences of each group (i.e., $\left|C D_{i}-\mathrm{CD}_{j}\right|$, where $i$ and $j$ are different colonies) using nested linear models and residual permutation procedures (RPP, see Turner et al., 2010 for statistical details). As centroid is the mean value of a given group in the $\delta^{13} \mathrm{C}-\delta^{15} \mathrm{~N}$ biplot, its location represents the core of the aggregation. Therefore, if $\mathrm{CL}$ distances between groups are statistically significant, a difference between the diets of each group could be expected. Then, if the absolute value of the difference of $C D$ between colonies differs from zero, a difference in trophic niche width and resource use could be assumed (Turner et al., 2010). Additionally, to estimate the isotopic niche for each colony and the isotopic overlap between colonies, standard ellipse areas corrected for small sample size $\left(S E A_{C}\right)$ and Bayesian estimate of the standard ellipse and its area $\left(S E A_{B}\right)$, both expressed in $\%{ }^{2}$, were calculated using the SIBER packages (Stable Isotope Bayesian Ellipses in R; Jackson, Inger, Parnell, \& Bearhop, 2011). The SEA (which contains $40 \%$ of the data regardless of sample size) represents the core of the isotopic niche of females from different colonies (Jackson et al., 2011, 2012; Jackson \& Britton, 2013). While the $S E A_{B}$ allows for the estimation of confidence intervals for isotopic niche areas (95\% in this case) (Jackson et al., 2011), and were used for statistical comparisons of the sizes of isotope niche widths among colonies, as a measure of the differences of isotopic resource use areas. Overlap in SEA $A_{B}$ among colonies (Jackson \& Britton, 2013) was used as a quantitative measure of dietary similarity between colonies, and was calculated as the overlap index, where a value $>1$ indicates significant overlap between groups (PáezRosas, Rodríguez Pérez, \& Riofrío Lazo, 2014). 
To consider whether the fine scale genetic population structure in adult female SASLs is related to their foraging ecology, samples were grouped according to spatial genetic similarities (Grandi et al., 2018). Isotopic niches from north and south zones were estimated by computing CR, NR, CL, and CD metrics (Layman et al., 2007; Turner et al., 2010). Differences between zones were explored separately for $\delta^{15} \mathrm{~N}$ and $\delta^{13} \mathrm{C}$ ranges using the MannWhitney $U$ test, for $C L$ and $C D$ using RPP (Turner et al., 2010). SEA, , SEA $A_{B}$, and overlap index were also calculated by zones in SIBER (Jackson \& Britton, 2013; Jackson et al., 2011). All calculations and iterative procedures were written and performed in the R language ( $R$ Core Team, 2019).

\section{3 | RESULTS}

\section{1 | Isotopic niche of SASL females belonging to 10 different colonies of northern Patagonia}

The mean $\delta^{13} \mathrm{C}$ and $\delta^{15} \mathrm{~N}$ values for 101 skin samples were $-13.90 \%$ o $0.59 \%$ ond $21.76 \%$ $\pm 0.92 \%$, respectively. Skin samples C:N ratio was $2.90 \pm 0.08$, indicating good lipid removal efficiency (Newsome et al., 2010). No significant differences were found in mean $\delta^{13} \mathrm{C}$ values among colonies (ANOVA $F=1.83, d f=9, p=.073$ ). On the other hand, mean $\delta^{15} \mathrm{~N}$ values were significantly different among colonies (ANOVA $F=7.23, d f=9, p=.0000$; Table 1, Figure 2).

Comparisons among colonies with RPP revealed both that distance between centroids location (CL) and absolute value of the difference between mean Euclidean distance to centroid differed significantly from zero for some colonies (Table 1, Figure 3). Thus, PC and PL colonies occupied different locations in bivariate space than the rest of the colonies, and PB1 and PB2 occupied different locations in bivariate space among north zone's colonies. Likewise, low CD values indicate colonies (BB, LR, PB1, and PB2) with lower diet diversity and narrower niche width (Table 1). Moreover, isotopic niche area $\left(\mathrm{SEA}_{B}\right.$ ) varied significantly among colonies (ANOVA $F=2,014.8, d f=9, p=.0000$ ), indicating that BB, LR, PB1, and PB2 showed significantly smaller isotopic niches than the rest of the colonies (Figure 3B, Table 1). Finally, we did not find a significant overlap among ellipses for the majority of the colonies
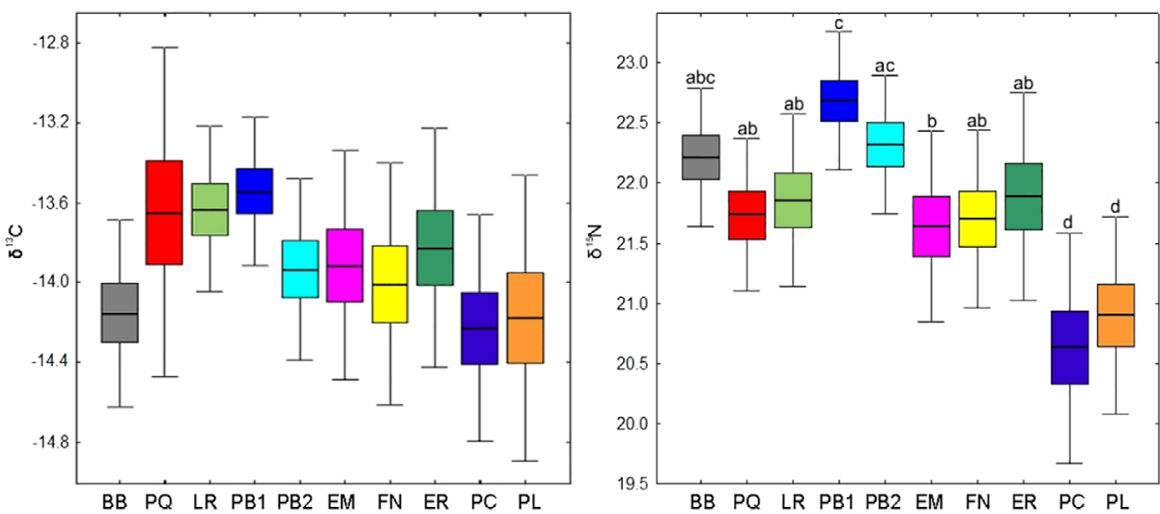

FIGURE 2 Mean stable carbon and nitrogen isotope ratios, (left) $\delta^{13} \mathrm{C}$ and (right) $\delta^{15} \mathrm{~N}$ skin of South American sea lion newborn pups from 10 colonies at northern Patagonia. Names of colonies (ID) are BB: Barrancas Blancas, PQ: Pta. Quiroga G. San José, LR: Larralde, PB1: Pta. Buenos Aires G. San José 1, PB2: Pta. Buenos Aires G. San José 2, EM: Ensenada Medina, FN: Faro Pta. Norte, ER: La Ernestina, PC: La Pastosa cría and PL: Pta. León Norte. Different lowercase letters indicate LSD post hoc statistically significant differences among colonies $(p<.05)$. 


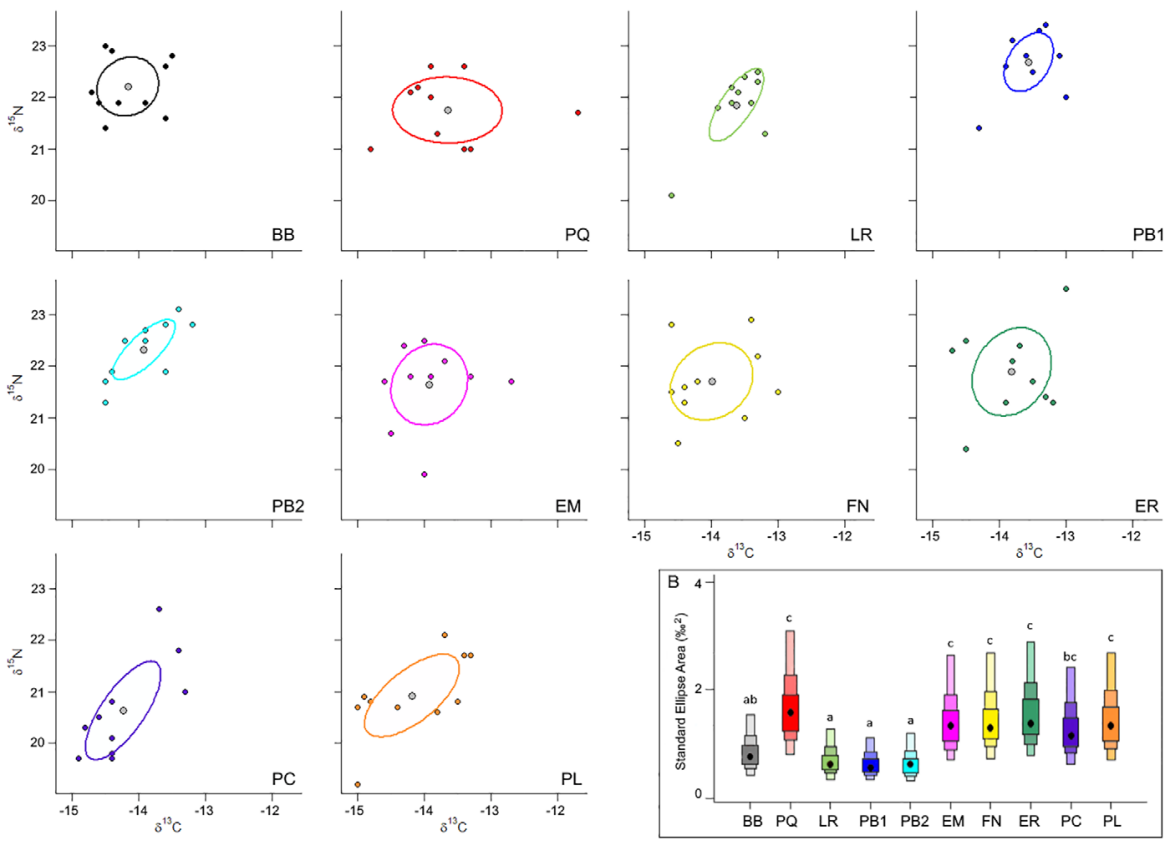

FIGURE 3 Standard ellipses areas (SEAc, 40\% credible interval) and centroids location (CL, gray dots) of South American sea lion newborn pups according to stable isotope ratios in skin from ten colonies at northern Patagonia. (Inset) Standard ellipse areas calculated based by Bayesian Inference for each SASL colony. Black dot represents their mode (\%o), the shaded boxes representing the 50\%,75\%, and $95 \%$ credibility intervals from dark to light color. Different lowercase letters indicate LSD post hoc statistically significant differences among colonies $(p<.05)$. Names of colonies (ID) are: BB: Barrancas Blancas, PQ: Pta. Quiroga G. San José, LR: Larralde, PB1: Pta. Buenos Aires G. San José 1, PB2: Pta. Buenos Aires G. San José 2, EM: Ensenada Medina, FN: Faro Pta. Norte, ER: La Ernestina, PC: La Pastosa cría and PL: Pta. León Norte.

(overlap index $<1$ ). However, some colonies from the north zone, showed a significantly isotopic niche overlap (i.e., overlap index $>1$; Figure 3, Table 2).

\subsection{Isotopic niche in relation to the fine scale genetic population structure in adult female SASLs}

When isotopes ratios were grouped according to spatial genetic similarities in north (BB, PQ, LR, PB2, PB1, $E M, F N$, and $E R$ ) and south colonies (PC and $P L)$, significant differences were found in both mean $\delta^{13} C$ and $\delta^{15} \mathrm{~N}$ values $\left(\delta^{13} \mathrm{C}: Z=2.22, d f=1, p=.026 ; \delta^{15} \mathrm{~N}: Z=4.90, d f=1, p=.000\right.$; Figure 4A, Table 3). RPP comparisons showed that distance between centroids differed significantly from zero between zones (distance $=1.296, p=.0001$; Table 3, Figure 4A). Besides, the absolute value of the difference of mean distance to centroid $(C D)$, did not differ significantly from zero between zones $\left(\left|C D_{\text {North }}-C D_{\text {South }}\right|=0.127, p=.271\right.$;

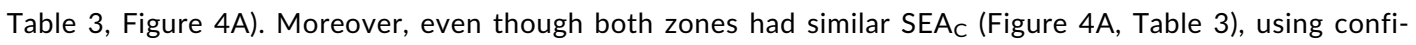
dence intervals obtained from Bayesian estimation of isotopic niche size $\left(S_{E} A_{B}\right)$ it was found that isotopic niches of south zone was significantly larger than those of north zone ( $t=13.25, d f=5604, p=.000)$, indicating a wider niche of females from south zone (Figure 4B). In addition, there was no significant overlap between the isotopic niche of north and south zones (overlap index $=0.18$ ) (Figure $4 \mathrm{~A}$ ). 

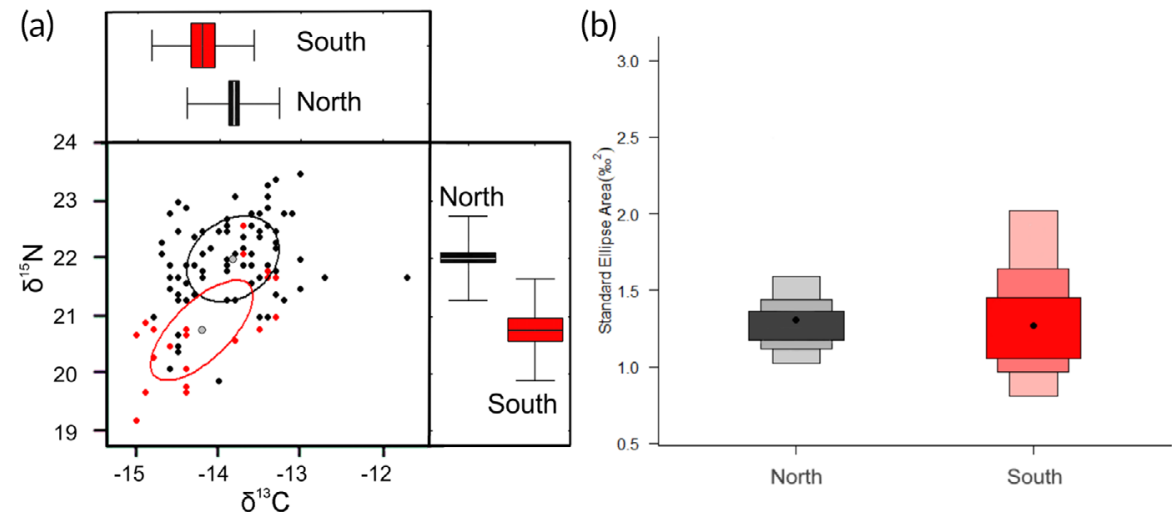

FI GURE 4 (A) Standard ellipses areas (SEA, $40 \%$ credible interval) and centroids location (CL, gray dots) of South American sea lion newborn pups according to stable isotope ratios in skin samples grouped by north (black) and south (red) colonies in northern Patagonia. Mean stable carbon and nitrogen isotope ratios, $\delta^{13} \mathrm{C}$ and $\delta^{15} \mathrm{~N}$ in north (black) and south (red) zones are shown in Figure margins. (B) Standard ellipse areas calculated based by Bayesian Inference by zones. Black dot represents their mode (\%), the shaded boxes representing the $50 \%, 75 \%$, and $95 \%$ credibility intervals from dark to light color: north (black) and south (red) zone.

TAB LE 3 Sample size, mean $( \pm S D)$ isotopic values in skin of South American sea lion newborn pups (\%), centroid location (CL), mean Euclidean distance to centroid $(C D)$ and Standard Ellipse Area $\left(S E A_{C}\right.$ and $S E A_{B}$ ) for each zone. *indicates statistically significant differences between zones $(p<.05)$.

\begin{tabular}{|c|c|c|c|c|c|c|c|c|}
\hline Zone & Colony ID & $\mathrm{n}$ & $\delta^{13} C( \pm S D)$ & $\delta^{15} \mathrm{~N}( \pm S D)$ & $\mathrm{CL}$ & $C D$ & $\mathrm{SEA}_{C}$ & $\operatorname{SEA}_{B}( \pm S D)$ \\
\hline North & $\begin{array}{l}\text { BB-PQ-LR-PB1- } \\
\text { PB2-EM-FN-ER }\end{array}$ & 81 & $-13.83 \pm 0.56^{*}$ & $22.01 \pm 0.75^{*}$ & $-13.83 ; 22.01^{*}$ & 0.813 & 1.296 & $1.30 \pm 0.15^{*}$ \\
\hline South & PC-PL & 20 & $-14.20 \pm 0.63^{*}$ & $20.76 \pm 0.88^{*}$ & $-14.20 ; 20.76^{*}$ & 0.940 & 1.321 & $1.37 \pm 0.32^{*}$ \\
\hline
\end{tabular}

\section{4 | DISCUSSION}

By measuring stable carbon and nitrogen isotope ratios in skin of SASL newborn pups at 10 different breeding colonies, we characterized the isotopic niche of their mothers during the last period of the pregnancy along the northern Patagonian coast. Overall, stable isotope ratios revealed a differential use of trophic resources and/or distinct foraging areas among females in different colonies. Differences found in most metrics studied (NR, CL, CD, SEA overlap, and $S E A_{B}$ ) reveal the plasticity of the species and support individual trophic specialization of SASL females at a small geographic scale.

The statistical analysis and the interpretation of the results reported here relies on two main assumptions:

(1) Carbon and nitrogen isotopic baseline do not vary along the coast of northern Patagonia. This assumption would be supported by the marine isoscape based on $\delta^{13} \mathrm{C}$ measured in phytoplankton (McMahon, Hamady, \& Thorrold, 2013), and the similar $\delta^{13} \mathrm{C}$ and $\delta^{15} \mathrm{~N}$ values presented by potential prey of SASLs at different latitudes over the Patagonian shelf (i.e., from northern Patagonia to the Fuegian archipelago; see Saporiti et al., 2015).

(2) Carbon and nitrogen isotope ratios in pups can be used directly as a proxy of the trophic ecology of their mothers. This is based on the empirical evidence that there are no significant differences in $\delta^{13} \mathrm{C}$ and $\delta^{15} \mathrm{~N}$ discrimination factors in skin of free-ranging female-to-pup (Drago et al., 2015). Nevertheless, it is important to highlight that ecological and physiological processes, play a fundamental role in the determination of the isotopic values of pups.

The isotopic niche amplitude of female SASLs during the last period of the pregnancy is concordant with the $\delta$ space defined by carbon and nitrogen isotopic values of potential preys reported for the species in northern 
Patagonia, after considering the trophic discriminator factor from consumer to prey (Drago et al., 2009). However, differences in most isotopic metrics analyzed were found, suggesting variation in the use of trophic resources by females among colonies. Colonies with higher $\delta^{15} \mathrm{~N}$ values indicate females feeding on a higher trophic position and/or bigger prey. Some colonies (BB, LR, PB1, and PB2) showed small isotopic niches and low trophic diversity (as differences between $C D$ and $S E A_{B}$ revealed), while some others (PQ, EM, FN, ER, PC, and PL) had larger isotopic niches as well as trophic diversity. Additionally, most females from different colonies had different positions in the delta space (as shown by low overlap index and CL location). In this sense, individual females from different colonies seem to vary their diet between available pelagic and benthic neritic resources over the Patagonian continental shelf. Unfortunately, movement and location at sea during the last period of the pregnancy of female SASLs that breed in the region are unknown. However, it is known that during the breeding season, lactating female SASLs belonging to northern Patagonia rookeries confine their foraging trips to the temperate waters of the Patagonian continental shelf, recording maximum travel distance of $258 \mathrm{~km}$ with a mean of $106.6 \pm 62.5 \mathrm{~km}$ from the colony (Campagna et al., 2001; Figure S1). In this sense, the consumption of neritic resources suggests that foraging areas of females during the last period of the pregnancy may be similar to feeding areas reported for the breeding season (Campagna et al., 2001). Moreover, considering satellite tracking data coming from Uruguayan rookeries, adult female SASLs foraging areas are quite similar during breeding and nonbreeding seasons (Riet-Sapriza et al., 2013; Rodríguez et al., 2013). On the other hand, female otariids are central place foragers that alternate foraging trips with nursing on land (Boyd, 1998). Lactation in SASL can last 8-12 months (Crespo, 1988, Ponce de León \& Pin, 2006; VazFerreira, 1982), and it is usual that lactating females nurse the newborn pup and a yearling (i.e., pup born in the previous breeding season) (Cárdenas-Alayza, Crespo, \& De Oliveira, 2016). Therefore, as lactating females have limited body reserves they depend on prey availability near the rookery to produce the milk needed to feed their pups throughout the year (Soto, Trites, \& Arias-Schreiber, 2004).

Differences between colonies found in the present study suggest two spatial grouping of the population. These findings are in agreement with data of satellite tracking of SASL females, genetic haplotypes, and SASL diet in northern Patagonia (Campagna et al., 2001; Grandi et al., 2018; Jarma et al., 2019).

Differences in mean $\delta^{13} \mathrm{C}$ and $\delta^{15} \mathrm{~N}$ values among individuals from the north and south zones, suggest some degree of segregation in the habitat use (Figure 1). According to this, most individuals from the north zone had relatively high $\delta^{13} \mathrm{C}$ and $\delta^{15} \mathrm{~N}$ values indicating benthic resources consumption, while a few individuals had relatively low $\delta^{13} \mathrm{C}$ and $\delta^{15} \mathrm{~N}$ values reflecting more consumption of pelagic resources. On the other hand, individuals from the south zone appear to exploit mainly pelagic resources, although benthic prey are still relevant to some individuals. Moreover, females from the south zone showed bigger isotopic niches and higher trophic diversity $\left(>|C D|\right.$ and $\left.S E A_{B}\right)$ than those from the north zone. Low SEA ${ }_{B}$ values found in sea lion females from the north zone may indicate a less diverse diet than females sampled in the south, according to the niche variation hypothesis, which states that populations with wider niches are more variable than populations with narrower niches (Van Valen, 1965). A wide isotopic niche of a marine species might be attributed to greater diet diversity within the population, as a consequence of higher variation in the area explored among individuals (Ceia, Paiva, Garthe, Marques, \& Ramos, 2014). Furthermore, females from the two zones showed differences among their diet (as shown by no SEA overlap and different CL location).

Evidence of dietary variations in SASLs among the north and south zones in the Patagonian region also comes from stomach content analysis. Evidence from individuals found dead in the north zone (San Matías Gulf; Figure 1), indicated feeding mostly on demersal/pelagic fish, whereas individuals close to the south zone (Nuevo Gulf; Figure 1) relied most heavily over benthic species (Jarma et al., 2019). The differences between the results presented in our study and those reported by Jarma et al. (2019) could be explained by two reasons. Firstly, the different methods used to study the foraging ecology of SASLs (i.e., stable isotope analysis vs. stomach content analysis) comprised different time windows. Stable carbon and nitrogen isotope ratios in skin samples are expected to integrate the last 3 months (i.e., from mid-November to mid-January) of the trophic ecology and physiology of SASLs, whereas hard remains in stomach contents are expected to represent food consumed in the last 24-72 hr. Secondly, by 
differences in age classes sampled: stomach content analysis relied on male and female SASLs belonging to all age classes (juveniles and adults), while our study focused only on adult pregnant females.

Alternatively, the assumption of a uniform isotopic baseline off the coast of northern Patagonia may not be sustained. This would be supported by changes of the $\delta^{13} \mathrm{C}$ and $\delta^{15} \mathrm{~N}$ values in suspended particulate organic matter found over the Patagonian shelf, between $41^{\circ}$ and $43^{\circ} \mathrm{S}$ (Lara et al., 2010). If this were the case, isotopic differences found among zones still stand, but they would be better explained by females feeding in two discrete foraging areas with distinct isotope baselines, although it is not clear if they feed on the same prey or not. Segregation of foraging areas of females during lactation is supported by the rare overlap at sea found in satellite tracked individuals from different rookeries in northern Patagonia (Campagna et al., 2001; Figure S1).

There is evidence of adult female SASLs from the Falkland Islands (Malvinas) rookeries foraging in discrete habitats: inshore (coastal), offshore (outer Patagonian shelf), and an intermediate (inshore/offshore) habitats (Baylis et al., 2015, 2016a). Baylis et al. (2016a) suggested that colony level differences in the habitat use of SASLs during the last period of the pregnancy reflect differences in the proximity of colonies to predictable oceanographic features, which may in turn influence the abundance, distribution, and prey availability. In northern Patagonia, during the austral late spring/early summer, different oceanographic features ${ }^{2}$ develops generating high productive areas (Figure 1). If SASL females from northern Patagonia choose those discrete habitats in which to forage, then colony level differences found in the present study could be related to its proximity to these high productive areas (Figure 1). However, future studies with satellite tracked sea lion to identify foraging discrete habitats are needed to complement isotopic data.

Specialization in different foraging strategies (i.e., inshore vs. offshore, or pelagic vs. benthic) or dependence on local habitat (such as oceanographic fronts, upwelling, etc.) may be acting or conditioning the female population structure within the SASL rookeries in northern Patagonia. Female foraging specialization within discrete fine scale foraging areas and habitats would constitute a plausible mechanism that drives genetic diversification and population structure. This has been true for Australian sea lions (Lowther et al., 2012) and Galapagos sea lions (Jeglinski et al., 2015). Moreover, if such behavioral specialization is maintained in the long-term, as is described for adult females SASLs from the Falkland Islands (Malvinas) (Baylis et al., 2015), it could be expected to contribute to the genetic population structure. At a smaller geographical scale, genetic population structure among colonies was found to be weak in northern Patagonia (Grandi et al., 2018). However, if differences in habitat use and fidelity to feeding ground of SASL females continued over time, these behaviors could drive the clustering of colonies and resulted in a strong genetic population structure. Thus, determining the ecological features that shape the genetic structure of marine top predators such as sea lions is challenging because their wide foraging habitat and high dispersal capabilities.

All in all, this study suggests that female SASLs from northern Patagonia have differential use of trophic resources and/or distinct foraging areas during the last period of the pregnancy among north and south colonies. Further research is needed to understand the relationship between the fine scale spatial genetic structure found by Grandi et al. (2018), and the foraging ecology of female SASLs (this study). Variation in individual specialization can influence the population stability and dynamics (Lima et al., 2019). Therefore, future studies integrating data on local oceanography conditions, satellite data of sea lion trips at sea, stable isotope, and genetic analyses are needed to fully understand the spatial population clustering in the context of a recovering population.

\section{ACKNOWLEDGMENTS}

We gratefully acknowledge L. Hückstädt and the two anonymous reviewers for their constructive comments and suggestions to improve the manuscript. This study was funded by the Agencia Nacional de Promoción Científica y Tecnológica (PICT 0216/2013), Zoo d'Amnéville, Fundación BBVA (BIOCON08 194/09) and Padi Foundation (Grant \#31802). Institutional and logistic support was given by Centro Nacional Patagónico (CCT CONICET-CENPAT) under permits of the Secretaría de Áreas Protegidas y Turismo and Dirección de Fauna y Flora Silvestre of Chubut Province. 


\section{AUTHOR CONTRIBUTIONS}

M. Florencia Grandi: Conceptualization; formal analysis; funding acquisition; investigation; methodology; writingoriginal draft; writing-review and editing. Damián Vales: Conceptualization; formal analysis; investigation; methodology; writing-review and editing. Enrique Crespo: Funding acquisition; writing-review and editing. Rocío Loizaga: Conceptualization; formal analysis; funding acquisition; investigation; methodology; writing-review and editing.

\section{ORCID}

M. Florencia Grandi (iD) https://orcid.org/0000-0002-1418-4205

Damián G. Vales (D) https://orcid.org/0000-0002-6252-1616

Enrique A. Crespo (D) https://orcid.org/0000-0001-9216-7817

Rocío Loizaga (D) https://orcid.org/0000-0001-5270-7401

\section{ENDNOTES}

${ }^{1}$ We consider Otaria flavescens (Shaw 1800) as the legal and valid species name for the South American sea lion, following most South American marine mammalogists and several works: Cabrera (1940), Crespo (1988), Lucero, Rodríguez, Teta, Cassini, \& D'Elía (2019), Rice (1998), Rodríguez \& Bastida (1993), and Vaz-Ferreira (1984).

2 Defined as: coastal upwelling events (Pisoni, Rivas, \& Piola, 2014), thermohaline front (Piola \& Scasso, 1988), and the Pensula Valdés tidal front (Tonini, Palma, \& Piola, 2013) and indicated in Figure 1 (right).

\section{REFERENCES}

Ameghino, S. P. (2012). Estudio de la inversión materna en crías de lobo marino de un pelo (Otaria flavescens, Shaw 1800) en dos colonias con distinta estructura social durante la temporada reproductiva [Study of maternal investment in sea lion pups (Otaria flavescens, Shaw 1800) in two colonies with different social structure during the reproductive season] (Graduate thesis). Universidad Nacional de la Patagonia San Juan Bosco, Chubut, Argentina.

Amos, W., \& Hoelzel, A. R. (1991). Long-term preservation of whale skin for DNA analysis. Report of the International Whaling Commission, Special Issue 13, 99-103.

Araújo, M. S., Bolnick, D. I., \& Layman, C. A. (2011). The ecological causes of individual specialisation. Ecology letters, 14, 948-958.

Aurioles, D., Koch, P. L., \& Le Boeuf, B. J. (2006). Differences in foraging location of Mexican and California elephant seals: Evidence from stable isotopes in pups. Marine Mammal Science, 22, 326-338.

Baylis, A. M., Kowalski, G. J., Voigt, C. C., Orben, R. A., Trillmich, F., Staniland, I. J., \& Hoffman, J. I. (2016a). Pup vibrissae stable isotopes reveal geographic differences in adult female southern sea lion habitat use during gestation. PloS ONE, 11, e0157394.

Baylis, A. M. M., Orben, R. A., Arnould, J. P. Y., Peters, K., Knox, T., Costa, D. P., \& Staniland, I. J. (2015). Diving deeper into individual foraging specializations of a large marine predator, the southern sea lion. Oecologia, 179, 1053-1065.

Baylis, A. M. M., Orben, R. A., Costa, D. P., Arnould, J. P. Y., \& Staniland, I. J. (2016b). Sexual segregation in habitat use is smaller than expected in a highly dimorphic marine predator, the southern sea lion. Marine Ecology Progress Series, 554, 201-211.

Bolnick, D. I., Svanbäck, R., Fordyce, J. A., Yang, L. H., Davis, J. M., Hulsey, C. D., \& Forister, M. L. (2003). The ecology of individuals: incidence and implications of individual specialization. The American Naturalist, 161, 1-28.

Boyd, I. L. (1998). Time and energy constraints in pinniped lactation. The American Naturalist, 152, 717-728.

Cabrera, A. (1940). Notas sobre carnivoros sudamericanos [Notes on South American carnivores]. Notas del Museo de La Plata (Zoología), 5, 1-22.

Campagna, C. (1985). The breeding cycle of the southern sea lion, Otaria byronia. Marine Mammal Science, 1, $210-218$.

Campagna, C., Werner, R., Karesh, W., Marín, M. R., Koontz, F., Cook, R., \& Koontz, C. (2001). Movements and location at sea of South American sea lions (Otaria flavescens). Journal of Zoology, 255, 205-220.

Capozzo, L. H., \& Perrin, W. F. (2009). South American sea lion, Otaria flavescens. In W. F. Perrin, B. Würsig, \& J. G. M. Thewissen (Eds.), Encyclopedia of marine mammals (pp. 1076-1079). Amsterdam, The Netherlands: Academic Press.

Cárdenas-Alayza, S., Crespo, E. A., \& Oliveira, L. (2016). Otaria byronia. The IUCN Red List of Threatened Species 2016: e.T41665A61948292. Available from https://doi.org/10.2305/IUCN.UK.2016-1.RLTS.T41665 A61948292.en

Ceia, F. R., Paiva, V. H., Garthe, S., Marques, J. C., \& Ramos, J. A. (2014). Can variations in the spatial distribution at sea and isotopic niche width be associated with consistency in the isotopic niche of a pelagic seabird species? Marine Biology, 161, 1861-1872. 
Collins, C. J., Chilvers, B. L., Osborne, A., Taylor, M., \& Robertson, B. C. (2017). Unique and isolated: Population structure has implications for management of the endangered New Zealand sea lion. Conservation Genetics, 18, 1177-1189.

Crawford, K., McDonald, R. A., \& Bearhop, S. (2008). Applications of stable isotope techniques to the ecology of mammals. Mammal Review, 38, 87-107.

Crespo, E. A. (1988). Dinámica poblacional del lobo marino de un pelo Otaria flavescens (Shaw, 1800), en el norte del litoral patagónico [Population dynamics of the sea lion Otaria flavescens (Shaw, 1800), in the northern Patagonian coast] (Ph.D. thesis). Universidad de Buenos Aires, Bueonos Aires, Argentina.

Drago, M., Cardona, L., Aguilar, A., Crespo, E. A., Ameghino, S., \& García, N. (2010). Diet of lactating South American sea lions, as inferred from stable isotopes, influences pup growth. Marine Mammal Science, 26, 309-323.

Drago, M., Crespo, E. A., Aguilar, A., Cardona, L., García, N., Dans, S. L., \& Goodall, N. (2009). Historic diet change of the South American sea lion in Patagonia as revealed by isotopic analysis. Marine Ecology Progress Series, 384, 273-286.

Drago, M., Franco-Trecu, V., Cardona, L., \& Inchausti, P. (2015). Diet-to-female and female-to-pup isotopic discrimination in South American sea lions. Rapid Communications in Mass Spectrometry, 29, 1513-1520.

Ducatez, S., Dalloyau, S., Richard, P., Guinet, C., \& Cherel, Y. (2008). Stable isotopes document winter trophic ecology and maternal investment of adult female southern elephant seals (Mirounga leonina) breeding at the Kerguelen Islands. Marine Biology, 155, 413-420.

Feijoo, M., Lessa, E. P., De Castro, R. L., \& Crespo, E. A. (2011). Mitochondrial and microsatellite assessment of population structure of South American sea lion (Otaria flavescens) in the Southwestern Atlantic Ocean. Marine Biology, 158, 1857-1867.

Franco-Trecu, V., Aurioles-Gamboa, D., Arim, M., \& Lima, M. (2012). Prepartum and postpartum trophic segregation between sympatrically breeding female Arctocephalus australis and Otaria flavescens. Journal of Mammalogy, 93, 514-521.

Franco-Trecu, V., Aurioles-Gamboa, D., \& Inchausti, P. (2014). Individual trophic specialisation and niche segregation explain the contrasting population trends of two sympatric otariids. Marine Biology, 161, 609-618.

Gentry, R. L., \& Holt, J. R. (1982). Equipment and techniques for handling northern fur seals (NOAA Technical Report NMFS SSRF-758). National Marine Fisheries Service, Seattle, WA: NOAA.

González Suárez, M., Flatz, R., Aurioles Gamboa, D., Hedrick, P. W., \& Gerber, L. R. (2009). Isolation by distance among California sea lion populations in Mexico: Redefining management stocks. Molecular Ecology, 18, 1088-1099.

Grandi, M. F., Dans, S. L., \& Crespo, E. A. (2008). Social composition and spatial distribution of colonies in an expanding population of South American sea lions. Journal of Mammalogy, 89, 1218-1228.

Grandi, M. F., Dans, S., \& Crespo, E. A. (2015). The recovery process of a population is not always the same: The case of Otaria flavescens. Marine Biology Research, 11, 225-235.

Grandi, M. F., Loizaga de Castro, R., Terán, E., Santos, M. R., Bailliet, G., \& Crespo, E. A. (2018). Is recolonization pattern related to female philopatry? An insight into a colonially breeding mammal. Mammalian Biology, 89, 21-29.

Hobson, K. A., Schell, D. M., Renouf, D., \& Noseworthy, E. (1996). Stable carbon and nitrogen isotopic fractionation between diet and tissues of captive seals: Implications for dietary reconstructions involving marine mammals. Canadian Journal of Fisheries and Aquatic Sciences, 53, 528-533.

Hoffman, J. I., \& Forcada, J. (2012). Extreme natal philopatry in female Antarctic fur seals (Arctocephalus gazella). Mammalian Biology, 77, 71-73.

Hoffman, J. I., Kowalski, G. J., Klimova, A., Eberhart-Phillips, L. J., Staniland, I. J., \& Baylis, A. M. M. (2016). Population structure and historical demography of South American sea lions provide insights into the catastrophic decline of a marine mammal population. Royal Society Open Science, 3, 160291.

Hoffman, J. I., Matson, C. W., Amos, W., Loughlin, T. R., \& Bickham, J. W. (2006). Deep genetic subdivision within a continuously distributed and highly vagile marine mammal, the Steller's sea lion (Eumetopias jubatus). Molecular Ecology, 15, 2821-2832.

Jackson, M. C., \& Britton, J. R. (2013). Variation in the trophic overlap of invasive Pseudorasbora parva and sympatric cyprinid fishes. Ecology of Freshwater Fish, 22, 654-657.

Jackson, A. L., Inger, R., Parnell, A. C., \& Bearhop, S. (2011). Comparing isotopic niche widths among and within communities: SIBER-Stable Isotope Bayesian Ellipses in R. Journal of Animal Ecology, 80, 595-602.

Jackson, M. C., Donohue, I., Jackson, A. L., Britton, J. R., Harper, D. M., \& Grey, J. (2012). Population-level metrics of trophic structure based on stable isotopes and their application to invasion ecology. PloS ONE, 7(2), e31757.

Jarma, D., Romero, M. A., García, N. A., Svendsen, G., González, R., Dans, S. L., \& Crespo, E. A. (2019). Small-scale variation in the diet of the South American Sea lion (Otaria flavescens) in northern Patagonia (Argentina). Regional Studies in Marine Science, 28, 100592.

Jeglinski, J. W., Wolf, J. B., Werner, C., Costa, D. P., \& Trillmich, F. (2015). Differences in foraging ecology align with genetically divergent ecotypes of a highly mobile marine top predator. Oecologia, 179, 1041-1052.

Kernaléguen, L., Arnould, J. P., Guinet, C., \& Cherel, Y. (2015). Determinants of individual foraging specialization in large marine vertebrates, the Antarctic and subantarctic fur seals. Journal of Animal Ecology, 84, 1081-1091. 
Koen Alonso, M., Crespo, E. A., Pedraza, S. N., García, N. A., \& Coscarella, M. A. (2000). Food habits of the South American sea lion, Otaria flavescens, off Patagonia, Argentina. Fisheries Bulletin, 98, 250-263.

Kurle, C. M., \& Worthy, G. A. (2001). Stable isotope assessment of temporal and geographic differences in feeding ecology of northern fur seals (Callorhinus ursinus) and their prey. Oecologia, 126, 254-265.

Lara, R. J., Alder, V., Franzosi, C. A., \& Kattner, G. (2010). Characteristics of suspended particulate organic matter in the southwestern Atlantic: Influence of temperature, nutrient and phytoplankton features on the stable isotope signature. Journal of Marine Systems, 79(1-2), 199-209.

Layman, C. A., Arrington, D. A., Montana, C. G., \& Post, D. M. (2007). Can stable isotope ratios provide quantitative measures of trophic diversity within food webs. Ecology, 88, 42-48.

Lima, R. C., Franco-Trecu, V., Vales, D. G., Inchausti, P., Secchi, E. R., \& Botta, S. (2019). Individual foraging specialization and sexual niche segregation in South American fur seals. Marine Biology, 166, 32.

Lowther, A. D., Harcourt, R. G., \& Goldsworthy, S. D. (2013). Regional variation in trophic ecology of adult female Australian sea lions inferred from stable isotopes in whiskers. Wildlife Research, 40, 303-311.

Lowther, A. D., Harcourt, R. G., Goldsworthy, S. D., \& Stow, A. (2012). Population structure of adult female Australian sea lions is driven by fine-scale foraging site fidelity. Animal Behaviour, 83, 691-701.

Lucero, S., Rodríguez, S. M., Teta, P., Cassini, G., \& D'Elia, G. (2019). Solving a long-standing nomenclatorial controversy: Designation of a neotype for the southern sea lion Otaria flavescens (Shaw, 1800). Zootaxa, 4555, 296-300.

Matich, P., Heithaus, M. R., \& Layman, C. A. (2011). Contrasting patterns of individual specialization and trophic coupling in two marine apex predators. Journal of Animal Ecology, 80, 294-305.

McMahon, K. W., Hamady, L. L., \& Thorrold, S. R. (2013). A review of ecogeochemistry approaches to estimating movements of marine animals. Limnology and Oceanography, 58, 697-714.

Micheli, F., \& Halpern, B. S. (2005). Low functional redundancy in coastal marine assemblages. Ecology Letters, 8, 391-400.

Newsome, S. D., Chivers, S. J., \& Berman Kowalewski, M. (2018). The influence of lipid extraction and long term DMSO preservation on carbon $\left(\delta^{13} \mathrm{C}\right)$ and nitrogen $\left(\delta^{15} \mathrm{~N}\right)$ isotope values in cetacean skin. Marine Mammal Science, 34, 277-293.

Newsome, S. D., Clementz, M. T., \& Koch, P. L. (2010). Using stable isotope biogeochemistry to study marine mammal ecology. Marine Mammal Science, 26, 509-572.

Newsome, T. M., Dellinger, J. A., Pavey, C. R., Ripple, W. J., Shores, C. R., Wirsing, A. J., \& Dickman, C. R. (2015). The ecological effects of providing resource subsidies to predators. Global Ecology and Biogeography, 24, 1-11.

Newsome, S. D., Koch, P. L., Etnier, M. A., \& Aurioles Gamboa, D. (2006). Using carbon and nitrogen isotope values to investigate maternal strategies in northeast Pacific otariids. Marine Mammal Science, 22, 556-572.

Oliveira, L. R., Gehara, M. C., Fraga, L. D., Lopes, F., Túnez, J. I., Cassini, M. H., ... García, N. (2017). Ancient female philopatry, asymmetric male gene flow, and synchronous population expansion support the influence of climatic oscillations on the evolution of South American sea lion (Otaria flavescens). PloS ONE, 12(6), e0179442.

Páez-Rosas, D., Rodríguez-Pérez, M., \& Riofrío-Lazo, M. (2014). Competition influence in the segregation of the trophic niche of otariids: A case study using isotopic Bayesian mixing models in Galapagos pinnipeds. Rapid Communications in Mass Spectrometry, 28, 2550-2558.

Páez-Rosas, D., Villegas-Amtmann, S., \& Costa, D. (2017). Intraspecific variation in feeding strategies of Galapagos sea lions: A case of trophic specialization. PloS ONE, 12(10), e0185165.

Pettorelli, N., Coulson, T., Durant, S. M., \& Gaillard, J. M. (2011). Predation, individual variability and vertebrate population dynamics. Oecologia, 167, 305-314.

Piola, A. R., \& Scasso, L. M. (1988). Circulación en el Golfo San Matías [Circulation in the San Matías Gulf]. GeoActa, 15, 33-51.

Pisoni, J. P., Rivas, A. L., \& Piola, A. R. (2014). Satellite remote sensing reveals coastal upwelling events in the San Matías Gulf-Northern Patagonia. Remote Sensing of Environment, 152, 270-278.

Ponce de León, A., \& Pin, O. D. (2006). Distribución, reproducción y alimentación del lobo fino Arctocephalus australis y del león marino Otaria flavescens en Uruguay [Distribution, reproduction and feeding of the fur seal Arctocephalus australis and the sea lion Otaria flavescens in Uruguay]. In R. Menafra, L. Rodríguez-Gallego, F. Scarabino, \& D. Conde (Eds.), Bases para la conservación y el manejo de la costa uruguaya [Basis for the conservation and management of the Uruguayan coast] (pp. 305-313). Montevideo, Uruguay: Vida Silvestre.

Post, D. M. (2002). Using stable isotopes to estimate trophic position: Models, methods, and assumptions. Ecology, 83, 703-718.

R Core Team. (2019). R: A language and environment for statistical computing. Vienna, Austria: R Foundation for Statistical Computing.

Rice, D. W. (1998). Marine mammals of the world. Special Publication No. 4, Society for Marine Mammalogy.

Riet-Sapriza, F. G., Costa, D. P., Franco-Trecu, V., Marín, Y., Chocca, J., González, B., ... Hückstadt, L. A. (2013). Foraging behavior of lactating South American sea lions (Otaria flavescens) and spatial-temporal resource overlap with the Uruguayan fisheries. Deep Sea Research Part II: Topical Studies in Oceanography, 88, 106-119. 
Rodríguez, D. H., \& Bastida, R. O. (1993). The southern sea lion, Otaria byronia or Otaria flavescens? Marine Mammal Science, 9, 372-381.

Rodríguez, D. H., Dassis, M., Ponce de León, A., Barreiro, C., Farenga, M., Bastida, R. O., \& Davis, R. W. (2013). Foraging strategies of southern sea lion females in the La Plata River Estuary (Argentina-Uruguay). Deep Sea Research Part II: Topical Studies in Oceanography, 88, 120-130.

Saporiti, F., Bearhop, S., Vales, D. G., Silva, L., Zenteno, L., Tavares, M., ... Cardona, L. (2015). Latitudinal changes in the structure of marine food webs in the Southwestern Atlantic Ocean. Marine Ecology Progress Series, 538, 23-34.

Sepúlveda, M., Pavez, G., Santos Carvallo, M., Balbontín, C., Pequeño, G., \& Newsome, S. D. (2017). Spatial, temporal, age, and sex related variation in the diet of South American sea lions in southern Chile. Marine Mammal Science, 33, $480-495$.

Soto, K. H., Trites, A. W., \& Arias-Schreiber, M. (2004). The effects of prey availability on pup mortality and the timing of birth of South American sea lions (Otaria flavescens) in Peru. Journal of Zoology, 264, 419-428.

Szteren, D., Naya, D. E., \& Arim, M. (2004). Overlap between pinniped summer diet and artisanal fishery catches in Uruguay. Latin American Journal of Aquatic Mammals, 3, 119-125.

Thompson, D., Duck, C. D., McConnell, B. J., \& Garrett, J. (1998). Foraging behaviour and diet of lactating female southern sea lions (Otaria flavescens) in the Falkland Islands. Journal of Zoology, 246, 135-146.

Tonini, M. H., Palma, E. D., \& Piola, A. R. (2013). A numerical study of gyres, thermal fronts and seasonal circulation in austral semi-enclosed gulfs. Continental Shelf Research, 65, 97-110.

Túnez, J. I., Centrón, D., Cappozzo, H. L., \& Cassini, M. H. (2007). Geographic distribution and diversity of mitochondrial DNA haplotypes in South American sea lions (Otaria flavescens) and fur seals (Arctocephalus australis). Mammalian Biology, 72, 193-203.

Túnez, J. I., Cappozzo, H. L., Nardelli, M., \& Cassini, M. H. (2010). Population genetic structure and historical population dynamics of the South American sea lion, Otaria flavescens, in north-central Patagonia. Genetica, 138, 831-841.

Turner, T. F., Collyer, M. L., \& Krabbenhoft, T. J. (2010). A general hypothesis testing framework for stable isotope ratios in ecological studies. Ecology, 91, 2227-2233.

Van Valen, L. (1965). Morphological variation and width of ecological niche. American Naturalist, 99, 377-390.

Vander Zanden, M. J., \& Rasmussen, J. B. (1999). Primary consumer $\delta^{13} \mathrm{C}$ and $\delta^{15} \mathrm{~N}$ and the trophic position of aquatic consumers. Ecology, 80, 1395-1404.

Vaz-Ferreira, R. (1982). Otaria flavescens (Shaw) South American sea lion. Mammals in the seas: Small cetaceans, seals, sirenians and otters (Vol. 4, pp. 477-495). Rome, Italy: Food and Agriculture Organization of the United Nations.

Vaz-Ferreira, R. (1984). Sobre el nombre cientifico del león marino sudamericano (Pinnipedia: Otariidae) [On the scientific name of the South American sea lion (Pinnipedia: Otariidae)]. Boletín de la Sociedad Zoológica del Uruguay, 2, 22-26.

\section{SUPPORTING INFORMATION}

Additional supporting information may be found online in the Supporting Information section at the end of this article.

How to cite this article: Grandi MF, Vales DG, Crespo EA, Loizaga R. Variation in trophic resources in female South American sea lions at a small geographic scale. Mar Mam Sci. 2021;37:314-327. https://doi.org/10. $\underline{1111 / \mathrm{mms} .12746}$ 